\title{
PENERAPAN MEDIA AURORA ANIMASI 3D MAKER UNTUK MENINGKATKAN HASIL BELAJAR KOGNITIF MAHASISWA BIOLOGI IKIP BUDI UTOMO MALANG
}

\author{
Riyanto $^{1}$, Lis Susilawati ${ }^{2}$ \\ ${ }^{1}$ Pendidikan Biologi, IKIP Budi Utomo, Malang \\ ${ }^{2}$ Pendidikan Bahasa dan Sastra Indonesia, IKIP Budi Utomo, Malang \\ e-mail: riyanto@budiutomomalang.ac.id
}

\begin{abstract}
ABSTRAK
Rendahnya pemahaman mahasiswa pada pembelajaran Genetika materi sinstesis protein. Penelitian ini bertujuan untuk mengetahui peningkatan hasil belajar kognitif melalui media Aurora 3D Animation Maker pada mata kuliah Genetika Mahasiswa Pendidikan Biologi 2016-A IKIP Budi Utomo Malang. Pendekatan penelitian yang digunakan adalah kualitatif dan jenis penelitiannya adalah Penelitian Tindakan Kelas (PTK). Instrumen yang digunakan adalah alat belajar, catatan lapangan, pertanyaan tes, dan dokumentasi. Pengambilan data dilakukan dengan tes formatif. Subjek penelitian ini adalah mahasiswa Biologi berjumlah 45 siswa. Hasil penelitian menunjukkan bahwa penerapan media Aurora untuk 3D Maker Animation dapat meningkatkan hasil belajar kognitif siswa Biologi 2016-A, dengan hasil belajar kognitif dengan ketuntasan klasikal $71 \%$ hingga $88 \%$. Berdasarkan data ini dapat disimpulkan bahwa penerapan media Aurora 3D Animation Maker dapat meningkatkan Hasil Belajar Kognitif mahasiswa Biologi 2016 IBU.
\end{abstract}

Kata kunci: Aurora animasi 3D maker, hasil belajar, genetika.

\section{ABSTRACT}

The low understanding of students in learning the genetics of protein synthesis material. This study aims to determine the increase in cognitive learning outcomes through Aurora media 3D Maker Animation in the Genetics course of the 2016-A Biology Education Student of IKIP Budi Utomo Malang.he research approach used is qualitative and the type of research is Classroom Action Research (CAR). The instruments used were learning tools, field notes, test questions, and documentation. Data retrieval is done by formative tests. The subject of this research is the Biology student amounts to 45 students. The results showed that the application of Aurora media to 3D Maker Animation can improve the Cognitive learning outcomes of 2016-A Biology students, with cognitive learning outcomes with classical completeness $71 \%$ to $88 \%$. Based on these data it can be concluded that the application of Aurora media 3D Maker Animation can improve the Cognitive Learning Outcomes of 2016 Biology students IBU.

Keywords: Aurora animasi 3D maker, learning outcomes, genetics.

Submitted: 13 Juni 2019

Accepted: 14 Juni 2019

Published: 05 Juli 2019

\section{PENDAHULUAN}

Kemajuan suatu bangsa sangat ditentukan oleh kualitas sumber daya manusia sedangkan kualitas sumber daya manusia tergantung pada kualitas pendidikannya. Peran pendidikan sangat 
Vol. 04, No. 01 : Hal. 52 - 56

Februari 2019

penting untuk menciptakan masyarakat yang cerdas, damai, terbuka, dan demokratis. Oleh karena itu pembaharuan pendidikan harus selalu dilakukan untuk meningkatkan kualitas pendidikan suatu bangsa.Pendidikan mempunyai peranan yang sangat penting dalam menciptakan sumber daya manusia (SDM) yang berkualitas. Di dalam Undang-Undang No.20 tahun 2003 tentang sistem pendidikan Nasional, tercantum pengertian pendidikan: yakni usaha sadar dan terencana untuk mewujudkan suasana belajar dan proses pembelajaran agar peserta didik secara aktif mengembangkan potensi dirinya sehingga memiliki kekuatan spiritual keagamaan, pengendalian diri, kepribadian, kecerdasan, akhlak mulia, dan keterampilan yang diperlukan oleh dirinya, masyarakat, bangsa dan negara (Ali, 2009).

IKIP Budi Utomo Malang adalah salah satu Lembaga Pendidikan Tenaga Kependidikan (LPTK) yang bertugas menyiapkan tenaga-tenaga kependidikan di berbagai jenis program studi, jenjang ( $\mathrm{S}$ 1, S2), dan jalur pendidikan (formal dan non formal). Di dalam peranannya dalam dunia pendidikan IKIP Budi Utomo malang senantiasa berusaha untuk melakukan sebuah pembaharuan pendidikan melalui berbagai riset kependidikan yang dimaksudkan agar dapat mengembangkan konsep pembelajaran dan mengupdate sistem pembelajaran yang inovatif. Seiring perkembangan zaman maka tuntutan pendidikan akan kualitas SDM semakin menjadi sorotan publik (Riyanto \& Ardiyansah, 2017).

Berdasarkan hasil observasi di IKIP Budi Utomo Malang menunjukkan bahwa pemahaman mahasiswa pada mata kuliah Genetika khusus pada materi sintesis protein masih rendah. Mahasiswa menganggap pembelajaran yang sangat sulit dipahami dan dimengerti, sehingga menyebabkan hasil belajar mahasiswa menjadi kurang.

Mengingat tingginya tingkat kesulitan materi dan belum digunakannya media Pembelajaran Inovatif maka diperlukan adanya inovasi pembelajaran salah satunya dengan menggunakan media Aurora Animasi 3D Maker. Aurora 3D Animation Maker merupakan software aplikasi yang dapat digunakan untuk membuat dan mendesain teks atau logo 3D yang indah dan penuh kreasi secara professional. Dengan Aurora 3D Animation Maker membuat beragam teks dan logo dengan menggunakan efek visual 3D yang sangat bagus. Kompatibilitas penuh dengan Photoshop, llustrator, iMovie, Final Cut, Premiere, dan sebagainya. Aurora 3D Text Maker merupakan software aplikasi yang digunakan membuat teks dan logo dengan efek 3D yang sangat cocok untuk mengembangkan bahan ajar interaktif. Dengan Aurora 3D Text Maker dapat membuat beragam teks dan logo secara cepat dan mudah sehingga bahan ajar yang dihasilkan diharapkan mampu melibatkan mahasiswa secara aktif dan memberdayakan kompetensi abad 21, (Rahmawati, 2013).

Penelitian Mutasim dan Suyitno (2016) menunjukkan bahwa media yang dikembangkan dengan Aurora animation $3 D$ maker termasuk dalam kategori sangat baik karena mampu meningkatkan aktivitas belajar mahasiswa sehingga pembelajaran dikelas akan lebih efektif dan efisien selanjutnya menurut Caswanto (2013), Penggunaan Media Aurora animation 3D maker dapat meningkatkan motivasi belajar mahasiswa. Penerapan mediaAurora Animasi 3D Maker diharapkan dapat menciptakan iklim belajar yang menyenangkan, dan menarik perhatian 
Vol. 04, No. 01 : Hal. 52 - 56

Februari 2019

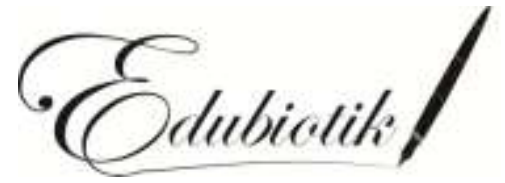

mahasiswa pendidikan Biologi IKIP Budi Utomo Malang. Berdasarkan latar belakang diatas, serta perlu ditingkatkannya motivasi dan hasil belajar mahasiswapadamatakuliahGenetika, maka pelu dilakukan penelitian tentang penerapan media aurora animasi 3D maker pada mata kuliah genetika untuk meningkatkan hasil belajar kognitif mahasiswa BiologiIKIP Budi Utomo Malang.

\section{METODE PENELITIAN}

Pendekatan yang digunakan dalam penelitian ini adalah pendekatan kualitatif dan jenis penelitian adalah Penelitian Tindakan Kelas (PTK) atau Classroom Action Research. Dalam penelitian akan dilakukan 2 siklus yang masing-masing terdiri dari 4 tahap. Desain penelitian yang digunakan terdiri dari 4 komponen yaitu perencanaan, tindakan, pengamatan (observasi), dan refleksi (Sanjaya, 2016).

Waktu penelitian dilakukan pada bulan Juni s/d Juli 2018 dan lokasi penelitian di Program Studi Pendidikan Biologi IKIP Budi utomo Malang. Penelitian terdiri dari 2 siklus (satu siklusnya dua kali tatap muka) dan waktu penelitiannya pada hari Kamis tanggal 15 Juni 2018 dan 29 Juli 2017 untuk siklus I, sedangkan hari Kamis tanggal 5 Juni 2017 dan hari Selasa tanggal 17 Juni 2018 untuk siklus II.

Prestasi hasil siklus I, II dan observasi awal dianalisis untuk mengetahui ketuntasan belajar siswa dan daya serap klasikal. Hal ini dilakukan dengan menganalisis nilai tes formatif menggunakan kriteria ketuntasan belajar. Tujuannya untuk mengetahui daya serap siswa dimana seorang siswa disebut tuntas belajar jika mencapai rerata skor $\geq 75$ dan daya serap klasikal $\geq 85 \%$.

Sedangkan peningkatan prestasi belajar didapat dengan membandingkan hasil prestasi pada siklus itu dengan prestasi awal atau sebelumnya (peningkatan prestasi pada siklus I dibandingkan dengan prestasi awal atau sebelum tindakan dan peningkatan prestasi pada siklus II dibandingkan dengan siklus I).

\section{HASIL DAN PEMBAHASAN}

Hasil penelitian berupa paparan data hasil pembelajaran tiap akhir siklus. Masing-masing tindakan itu memaparkan tentang: Hasil belajar kognitif mahasiswa dan analisis ketuntasan belajar klasikal tiap siklus. Adapun rincian penyajian hasil penelitian seperti Tabel 1 berikut.

Berdasarkan data pada Tabel 1 di bawah, diketahui ketuntasan belajar klasikal siklus I mencapai $71 \%$. Secara umum dapat disimpulkan hasil penelitian tindakan kelas siklus I termasuk 'Cukup Baik' karena 71\% mahasiswa tuntas belajar, di mana 27 mahasiswa yang tuntas dan 11 mahasiswa tidak tuntas.

Tabel 1. Persentase Ketuntasan Kasikal Hasil Tes Siklus I

\begin{tabular}{c|c|c|c|c}
\hline Nilai & N & Persentase & Akumulasi & T/TT \\
\hline$>85$ & 5 & $13 \%$ & $13 \%$ & \multirow{2}{*}{27 mahasiswa tuntas } \\
\cline { 1 - 3 } $75-85$ & 9 & $24 \%$ & $24 \%$ & \\
\hline $65-74$ & 13 & $34 \%$ & $34 \%$ & \multirow{2}{*}{$\begin{array}{c}\text { mahasiswa tidak } \\
\text { tuntas }\end{array}$} \\
\hline $50-64$ & 6 & $16 \%$ & - & \\
\hline$<50$ & 5 & $13 \%$ & - & \\
\hline Total & $\mathbf{3 8}$ & $\mathbf{1 0 0 \%}$ & $\mathbf{7 1 \%}$ & \\
\hline
\end{tabular}


Vol. 04, No. 01 : Hal ...-....

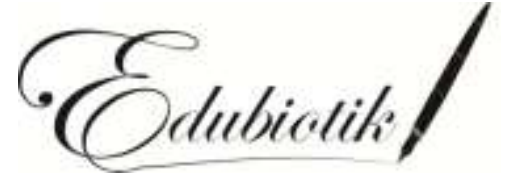

Februari 2019

Tabel 2. Persentase Ketuntasan Kasikal Hasil Tes Siklus II

\begin{tabular}{|c|c|c|c|c|}
\hline Nilai & $\mathbf{N}$ & Persentase & Akumulasi & T/TT \\
\hline$>85$ & 7 & $19 \%$ & $19 \%$ & \multirow{3}{*}{$\begin{array}{l}31 \text { mahasiswa } \\
\text { tuntas }\end{array}$} \\
\hline $75-85$ & 12 & $31 \%$ & $31 \%$ & \\
\hline $65-74$ & 12 & $38 \%$ & $38 \%$ & \\
\hline $50-64$ & 5 & $9 \%$ & - & \multirow{2}{*}{$\begin{array}{l}7 \text { mahasiswa } \\
\text { tidak tuntas }\end{array}$} \\
\hline$<50$ & 2 & $3 \%$ & - & \\
\hline Total & 38 & $100 \%$ & $88 \%$ & \\
\hline
\end{tabular}

Namun persentase tersebut belum mampu mencapai target ketuntasa sedangkan target ketuntasan klasikal minimal yang $80 \%$ mahasiswa tuntas belajar, oleh karena itu peneliti melanjutkan tindakan pada siklus II. Adapun rincian penyajian hasil penelitian siklus II seperti Tabel 2 di atas.

Berdasarkan data yang tercantum pada Tabel 2 di atas, diketahui ketuntasan belajar klasikal siklus II mencapai $88 \%$. Dengan jumlah 31 mahasiswa yang tuntas dan tidak tuntas berkurang menjadi 7 mahasiswa. Berdasarkan hasil belajar mahasiswa tersebut, maka dapat disimpulkan bahwa pelaksanaan tindakan siklus II pada mahasiswa kelas A angkatan 2016 IKIP budi Utomo Malang telah berhasil, di mana persentase ketuntasan belajar klasikal mencapai $88 \%$. Persentase ketuntasan ini telah melewati standar ketuntasan klasikal minimal $80 \%$, dengan telah tercapainya hasil tersebut maka penelitian ini dihentikan.

Peningkatan ketuntasan belajar mahasiswa pada siklus II antara lain disebabkan oleh meningkatnya keaktifan mahasiswa dalam proses belajar mengajar, di mana beberapa mahasiswa yang kurang aktif dalam pembelajaran pada siklus I dapat secara aktif berpartisipasi dengan bertanya, mengemukakan ide-ide, menguraikan materi, dan menyimpulkan materi pembelajaran seputar genetika. Selama pelaksanaan pembelajaran pada siklus I dan siklus II, dari hasil pengamatan dapat diketahui telah terjadi perubahan pada mahasiswa ke arah yang lebih baik hal itu sesuai dengan penelitian Rakhmawati (2013) Aurora animation 3D maker dapat menciptakan solusi yang efektif dan efisien untuk menarik perhatian mahasiswa. Penelitian Mutasim dan Suyitno (2016) menunjukkan bahwa media yang dikembangkan dengan Aurora animation 3D maker termasuk dalam kategori sangat baik karena mampu meningkatkan aaktivitas belajar mahasiswa sehingga pembelajaran di kelas akan lebih efektif dan efisien. Menurut Caswanto (2013), Penggunaan Media Aurora animation $3 D$ maker dapat meningkatkan motivasi belajar mahasiswa, selain itu berdasarkan hasil analisis data respon terhadap pembelajaran dengan menggunakan media Aurora animation 3D maker diperoleh rata-rata sebesar 86,87 yang termasuk dalam kategori tinggi dan hasil analisis data motivasi belajar mahasiswa diperoleh rata-rata sebesar 87,37 termasuk kategori baik. Aurora animation $3 D$ maker dapat digunakan untuk media pembelajaran berbasis multimedia interaktif, sehingga diharapkan dapat diterapkan dalam pembelajaran di kelas. Aurora animation 3D maker menggunakan cara yang efektif dan efisien dalam mengembangkan presentasi yang profesional dan menarik dalam berbagai format 3D. Menurut Riyanto (2015) penggunaan pembelajaran interaktif pada pembelajaran genetika dapat meningkatkan hasil belajarkognitif sampai $85,3 \%$ dan 
Vol. 04, No. 01 : Hal ...-....

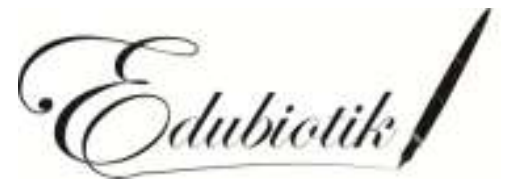

P-ISSN: 2528-679X

E-ISSN:2597-9833

pemahaman konsep mahasiswa sebesar $87,2 \%$.

\section{SIMPULAN DAN SARAN}

Berdasarkan uraian bahasan di atas dapat disimpulkan bahwa penerapan media aurora animasi 3D maker dapat meningkatkan hasil belajar kognitif mahasiswa Biologi 2016-A IBU. Aurora animasi 3D maker mampu meningkatkan hasil belajar mahasiswa di Pendidikan Biologi IKIP budi Utomo Malang, maka disarankan kepada dosen agar menggunakan dengan aurora animasi $3 D$ maker dalam proses belajar mengajar Biologi.

\section{RUJUKAKAN}

Ali, M. (2009). Pendidikan untuk pembangunan nasional: menuju bangsa Indonesia yang mandiri dan berdaya saing tinggi. Grasindo.

Caswanto Toto. (2013). Pengaruh Penggunaan Media Aurora 3D Presentation terhadap Motivasi Belajar Matematika Mahasiswa Kelas VIII di MTs.Salafiyah Kota Cirebon. Skripsi. Perpustakaan IAIN Syekh Nurjati Cirebon

Depdiknas. (2004). Pedoman Khusus Pengembangan Silabus dan Penilaian. Jakarta: Departemen Pendidikan Nasional, Direktorat Jenderal Pendidikan Dasar dan Menengah.

Rakhmawati, T. H. (2013). D Aurora Presentation 2.012 Sebagai Media Berbasis Multimedia Interaktif untuk Pembelajaran Bahasa Arab di MTs Negeri Bobotsari. Journal Program Sarjana Universitas Islam Negeri Sunan Kalijaga Yogyakarta, 5(1).

Riyanto, R. (2015). Pengembangan Modul Interaktif Pada Pembelajaran Genetika Untuk Meningkatkan Hasil Belajardan Pemahaman Konsep Siswa SMA Islam Batu. Jurnal Edukasi Matematika dan Sains, 3(2), 25-34.
Riyanto, R., \& Ardiyansah, B. (2017). Penerapan Media Karikatur Berbasis Sparkol Video Scribe Untuk Meningkatkan Hasil Belajar Kognetif Pada Matakuliah Genetika Mahasiswa Biologi Kalas-A Angkatan 2014-IBU. Edubiotik: Jurnal Pendidikan, Biologi dan Terapan, 2(02), 18-25.

Sanjaya, D. H. W. (2016). Penelitian tindakan kelas. Prenada Media.

Sudjana, Nana. 2005. Penilaian Hasil Proses Belajar Mengajar. Bandung: Remaja Rosdakarya. 